\title{
PENGARUH PEER ASSESSMENT DALAM MENINGKATKAN KETERAMPILAN ANAMNESIS DI SKILLS LABORATORY
}

\author{
Indah Puspasari Kiay Demak*, Amitya Kumara**, Efrayim Suryadi*** \\ *Fakultas Kedokteran dan Ilmu Kesehatan Universitas Tadulako, Palu \\ ** Fakultas Psikologi Universitas Gadjah Mada, Yogyakarta \\ ***Fakultas Kedokteran Universitas Gadjah Mada, Yogyakarta
}

\begin{abstract}
Background. Peer assessment is a breakthrough innovation in assessment method where students assess their fellows. The benefits of it are feedback, cognitive and metacognitve gain, motivation, collaborative learning, selfregulated learning and performance enhancement. Learning in skills laboratory, students are expected to be able to master not only knowledge but also skills. Peer assessment is expected to make students be more motivate in learning and enhance performance.

Objective. The aim of this study is to find out whether peer assessment can enhance students' medical interview skills in skills laboratory.

Method. The method was a quasi-experiment study with matching-only pretest posttest control group design. The subjects were third-year students in Medical School of Tadulako University which were divided into 2 experiment groups and 2 control groups. Before giving treatment, the skills of students in all group were assessed (pre test). After the treatment, post test was held as an evaluation tool. The raising score from pre test to post test will be analized with student $t$ test.

Results and Discussion. P value for raising score was 0,907 (á $>0.05$ ) with mean difference -0.091 , which means not signifance statistically. The negative number of mean difference indicate that the raising score in experiment group was lower than in control group.

Conclusion. Raising score in control group was higher than in experiment group, but not significance statistically. Application of peer assessment in skills laboratory should be more concern in students ability in assessing which can be obtain by intense training and continous monitoring and feedback from instructor.
\end{abstract}

Key words: peer assessment, medical interview skills, skills laboratory

\section{ABSTRAK}

Latar Belakang. Peer assessment merupakan inovasi dalam dunia pendidikan khususnya pada metode penilaian. Pada praktek peer assessment, mahasiswa saling menilai temannya. Manfaat dari peer assessment yaitu mendapatkan feedback, proses kognitif dan metakognitif, motivasi, collaborative learning, self-regulated learning, dan peningkatan performa. Pembelajaran di skillslab menuntut mahasiswa untuk menguasai teori dan terampil dalam melakukan keterampilan klinis. Penerapan peer assessment diharapkan dapat meningkatkan motivasi mahasiswa dalam belajar dan meningkatkan performa di skills lab.

Tujuan. Mengetahui apakah penerapan peer assessment di skills lab dapat meningkatkan performa keterampilan anamnesis mahasiswa

Metode. Penelitian ini merupakan penelitian kuantitatif menggunakan desain kuasi eksperimental tipe the matching-only pretest posttest control group design. Subjek penelitian adalah seluruh mahasiswa tahun ketiga Program Studi Pendidikan Dokter Universitas Tadulako. Mahasiswa dibagi menjadi 2 kelompok perlakuan dan 2 kelompok

Korespondensi: sashkata@yahoo.com; 085228525323 
kontrol. Mahasiswa diuji keterampilannya sebelum perlakuan diberikan (pretes), dan setelah dilakukan perlakuan mahasiswa diuji kembali (postes). Peningkatan nilai rata-rata dari pretes ke postes pada kelompok perlakuan dan kelompok kontrol akan dianalisis dengan uji student $t$.

Hasil. Nilai p peningkatan nilai rata-rata adalah 0,907 (á > 0,05) dengan rerata (mean difference) sebesar -0,09, yang berarti tidak terdapat perbedaan bermakna.

Kesimpulan. Peningkatan rata-rata nilai pada kelompok kontrol lebih tinggi daripada kelompok perlakuan, walaupun secara perhitungan statistik perbedaan tersebut tidak bermakna. Walaupun demikian, aplikasi metode peer assessment dapat dilaksanakan di skills laboratory dengan lebih memperhatikan kesiapan dan kemampuan mahasiswa dalam menilai. Hal ini dapat dicapai dengan cara pelatihan yang intens dan selalu diawasi oleh instruktur yang selalu memberikan feedback.

Kata kunci: peer assessment, keterampilan anamnesis, skills lab

\section{PENDAHULUAN}

Program Studi Pendidikan Dokter Universitas Tadulako (PSPD Untad) telah menggunakan metode pembelajaran klinik di skills lab sejak didirikan pada tahun 2008. Pelaksanaan praktikum keterampilan klinik di skills lab merupakan salah satu dari metode pembelajaran yang disukai oleh mahasiswa PSPD Untad berdasarkan hasil evaluasi blok yang dilakukan pada tahun 2009. Akan tetapi, pada beberapa bulan terakhir terjadi penurunan motivasi belajar dan penurunan prestasi akademik mahasiswa pada praktikum skills lab.

Penyebab turunnya motivasi belajar mahasiswa dapat berasal dari internal dan eksternal. Faktor internal berasal dari dalam diri mahasiswa berupa valuing dan expectations. ${ }^{(1)}$ Faktor eksternal berasal dari kondisi yang terjadi di skills lab. Pada survei yang diadakan pada bulan November 2010 tentang skills lab pada mahasiswa tahun ketiga, terdapat 2 faktor yang menurut mereka mempengaruhi proses pembelajaran, yaitu kelengkapan sarana prasarana dan sumber daya manusia. ${ }^{(2)}$

Peer assessment merupakan salah satu metode penilaian yang melibatkan mahasiswa. Boud et al. mendefinisikan peer assessment sebagai "the use of teaching and learning strategies in which students learn with and from each other without the immediate intervention of a teacher". (3) Pada pelaksanaan peer assessment, untuk mahasiswa dibagi menjadi 2, yaitu assessor dan assessee. Assessor adalah mahasiswa yang menilai, sedangkan assessee adalah mahasiswa yang dinilai. ${ }^{(4,5)}$
Keterlibatan mahasiswa dalam sistem penilaian memungkinkan mahasiswa untuk menjadi lebih aktif dalam belajar. Mahasiswa dapat merasakan menilai suatu materi sebelum mereka dinilai oleh dosen. Peer assessment menjadikan mahasiswa merasa lebih bertanggung jawab dan dapat mengidentifikasi kebutuhan belajar mereka sendiri. ${ }^{(6,7,8,9)}$

Pada proses peer assessment terdapat peer feedback. Proses peer assessment, mulai dari task performance, feedback provision, feedback reception, sampai feedback revision, memungkinkan terjadinya interaksi antar mahasiswa yang merangsang proses kognitif sehingga dapat mengantarkan pada elaborasi lebih dalam (deep learning) tentang materi yang dipelajari. Sebelum proses menilai, assessor harus mengetahui dahulu materi yang akan dinilai, sehingga akan belajar lebih keras untuk dapat memahami standar dan kriteria yang harus dinilai. Peer assessment menuntut mahasiswa menyediakan waktu lebih banyak dalam berpikir, membedakan, dan mengkomunikasikan hasil penilaiannya. Selain itu, proses assessor dalam mereview, menyimpulkan, mengklarifikasi, memberikan feedback, menetapkan kesalahpahaman, dan mengetahui kekurangan dari teman yang dinilai merupakan bentuk dari proses kognisi dan metakognisi. Hal yang dilakukan oleh assessor di atas membantu dalam konsolidasi, penguatan, dan pemahaman lebih dalam suatu materi. Bagi assessee, proses kognisi dan metakognisi terjadi pada pemahaman kriteria dan standar yang akan dinilai. ${ }^{(4,8)}$ Pada proses ini juga terjadi collaborative learning, yaitu 
mahasiswa saling bekerja sama mencapai hasil sesuai yang diinginkan oleh dosen. ${ }^{(10)}$

Proses peer assessment meningkatkan motivasi bagi mahasiswa. ${ }^{(11)}$ Peran motivasi sangat penting dalam proses belajar. Aktivitas mahasiswa yang terlibat dalam proses belajar lebih dalam (deep learning) berhubungan dengan keyakinan akan kemampuan (efficacy belief), status motivasi, dan tingkat percaya diri. ${ }^{(12)}$

\section{TUIUAN}

Penelitian ini dilakukan dengan tujuan untuk:

1. Mengetahui pengaruh aplikasi peer assessment pada keterampilan anamnesis mahasiswa saat praktikum di skills lab.

2. Mengetahui pendapat mahasiswa tentang manfaat pelaksanaan peer assessment di skills lab.

\section{METODE}

Penelitian ini merupakan penelitian kuantitatif menggunakan desain kuasi eksperimental tipe the matchingonly pretest posttest control group design. Subjek penelitian adalah seluruh mahasiswa tahun ketiga PSPD UNTAD Palu. Mahasiswa dibagi menjadi 4 kelompok sesuai dengan IPK (Indeks Prestasi Kumulatif), 2 kelompok diberi perlakuan dan 2 kelompok kontrol. Pada kelompok perlakuan dan kelompok kontrol rata-rata IPK mahasiswa adalah sama yaitu 2,97. Jumlah subjek penelitian adalah 47 mahasiswa. Pada kelompok perlakuan terdapat 23 mahasiswa, dan 24 mahasiswa pada kelompok kontrol.

Proses penelitian secara ringkas dapat dilihat pada gambar di bawah.

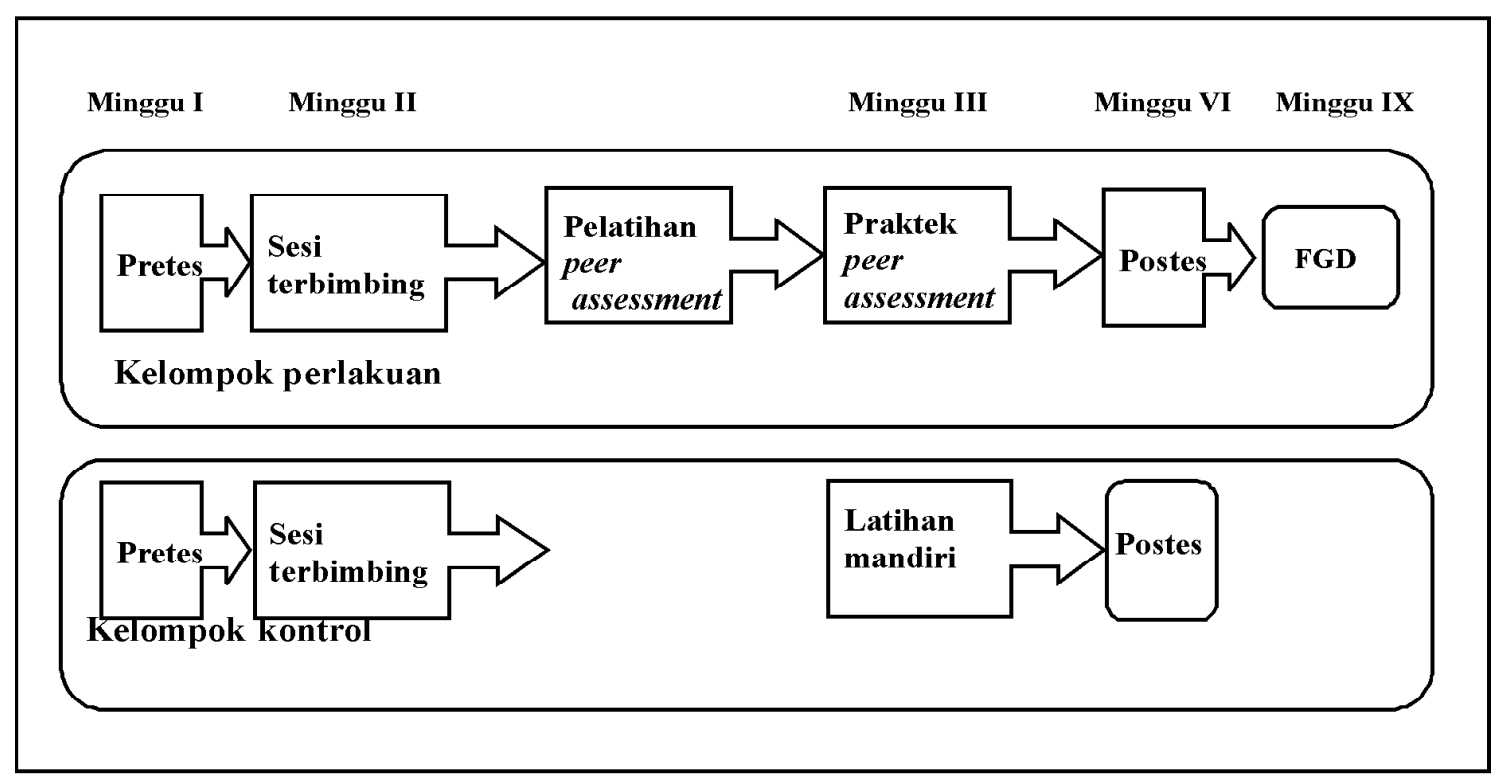

Gambar 1. Skema penelitian

1. Pretes

Pretes dilaksanakan sebelum praktikum skills lab dimulai. Seluruh mahasiswa dinilai menggunakan ceklis keterampilan klinik "Pemeriksaan Pediatri" oleh 2 orang instruktur. Masing-masing instruktur menilai 1 kelompok kontrol dan 1 kelompok perlakuan.
2. Sesi latihan terbimbing praktikum skills lab

Sesi ini dilaksanakan pada minggu kedua. Instruktur memberikan materi tentang "Pemeriksaan Pediatri” pada masing-masing kelompok. Instruktur yang memberikan materi adalah instruktur yang menilai pada pretes. Kedua instruktur tersebut juga yang akan menilai pada postes sesuai 
dengan kelompok pada saat pretes. Sesi ini berlangsung selama 2 jam.

3. Pelatihan peer assessment

Pelatihan peer assessment diikuti oleh seluruh mahasiswa pada kelompok perlakuan. Pelatihan terdiri dari 3 pertemuan. Pertemuan Pertama berupa pengenalan peer assessment, pemberian contoh role play dan praktek peer assessment. Pertemuan kedua berupa praktek peer assessment dan diskusi. Pertemuan ketiga berupa evaluasi kemampuan mahasiswa melakukan peer assessment.

4. Sesi latihan mandiri (praktek peer assessment pada kelompok perlakuan)

Pada sesi ini, mahasiswa dari kelompok kontrol melakukan latihan mandiri, yaitu mahasiswa melatih dirinya sendiri menggunakan fasilitas yang terdapat di ruangan praktikum.

Pada kelompok perlakuan, mahasiswa mempraktekkan peer assessment. Masing-masing mahasiswa dinilai oleh 6 teman dan diberi feedback oleh 2 teman dalam 1 kelompok. Daftar assessor dan assessee disusun oleh peneliti secara acak. Sesaat sebelum praktikum dimulai, mahasiswa telah memegang lembar penilaian peer assessment dan daftar nama teman yang akan dinilai dan diberi feedback. Mahasiswa kemudian satu persatu mempraktekkan keterampilan diikuti dengan proses pengisian lembar penilaian peer assessment oleh temannya. Assessee tidak mengetahui teman yang menilainya. Setelah melakukan praktek keterampilan, mahasiswa tersebut diberi feedback oleh 2 teman.

5. Sesi responsi (postes)

Sesi ini dilaksanakan pada minggu keenam. Pada sesi ini, mahasiswa satu persatu melakukan praktek keterampilan klinik dan dinilai oleh instruktur.
6. Focus group discussion

Focus group discussion (FGD) dilaksanakan pada minggu kesembilan selama 1 jam.

Instrumen yang digunakan oleh instruktur dalam menilai mahasiswa pada pretes dan postes adalah adalah ceklis keterampilan klinik "Anamnesis pada Pemeriksaan Pediatri” yang merupakan bagian dari ceklis "Pemeriksaan Pediatri". Terdapat 13 item pertanyaan yang berhubungan dengan keterampilan anamnesis pada ceklis ini. Ceklis tersebut terdapat dalam modul skills lab yang digunakan untuk penilaian instruktur. Terdapat 3 penilaian pada formulir ini, yaitu 0,1 , dan 2. Skor 0 berarti mahasiswa tidak melakukan. Skor 1 berarti mahasiswa melakukan dengan tidak sempurna. Skor 2 berarti mahasiswa melakukan dengan sempurna. Semua item soal memiliki bobot nilai 1, kecuali pada soal nomor 4 yang memiliki bobot nilai 2. Nilai terendah dari ceklis adalah 0 dan nilai tertinggi adalah 28. Instrumen yang digunakan mahasiswa dalam menilai temannya pada praktek peer assessment sama dengan instrumen yang dipakai oleh instruktur.

Panduan pertanyaan focus group discussion disusun berdasarkan manfaat peer assessment yang dikemukakan oleh Kollar \& Fischer ${ }^{(10)}$, Topping ${ }^{(8)}$, dan Topping(4). Pengambilan data berupa manfaat yang didapatkan dari pelaksanaan peer assessment ini bertujuan untuk mengetahui peran peer assess-ment dalam mempengaruhi belajar mahasiswa. ${ }^{(4,8,10)}$

\section{HASIL}

Pada kelompok kontrol, nilai rata-rata pretes adalah 17,13 (SD 2,365), dengan kisaran nilai 14-22. Pada kelompok perlakuan, nilai rata-rata pretes adalah 16,70 (SD 3,081) dengan kisaran nilai 11-24. Pada kelompok kontrol, nilai rata-rata postes adalah 25,04 (SD 1,574) dengan kisaran nilai 22-28. Pada kelompok perlakuan, nilai rata-rata pretes adalah 24,52 (SD 1,592) dengan kisaran nilai 20. 28. 


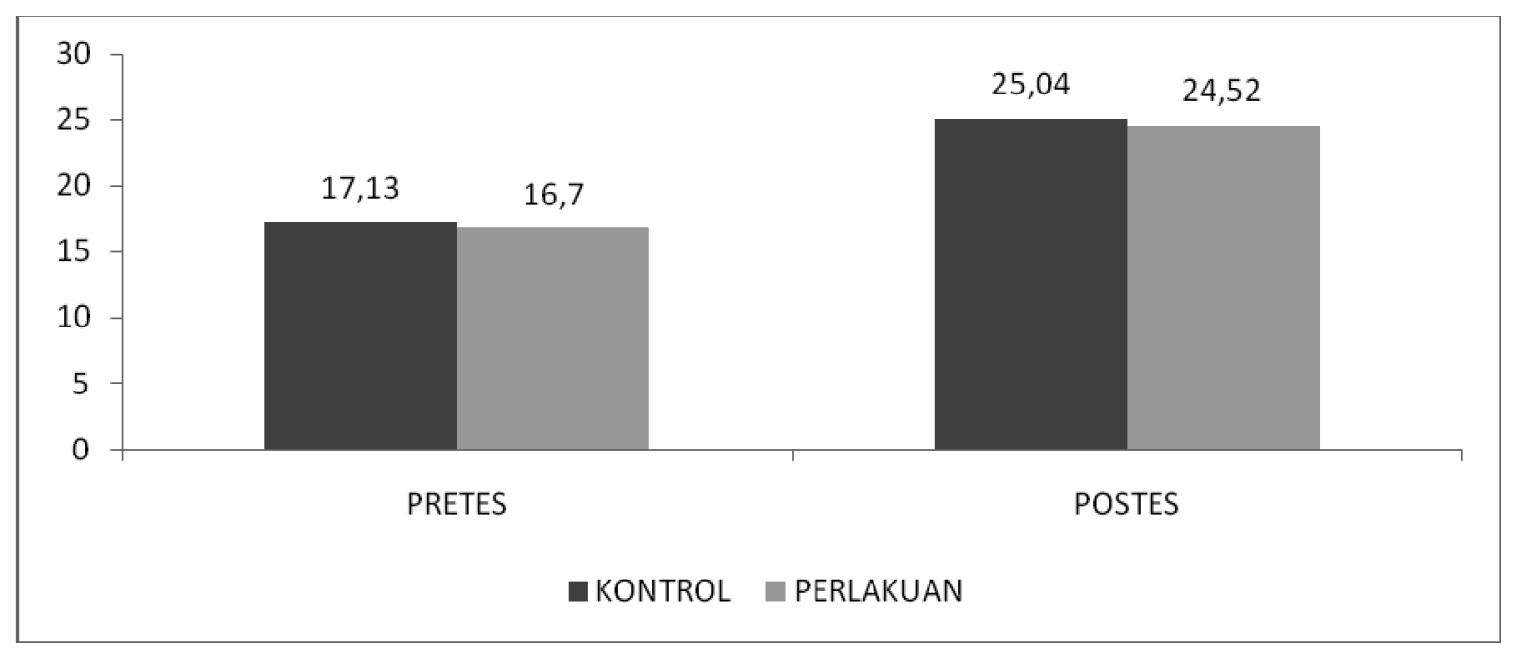

Gambar 2. Rata-rata nilai pretes dan postes pada kelompok kontrol dan kelompok perlakuan

Peningkatan nilai pretes ke postes pada kelompok kontrol adalah 7,92 (SD 2,466) dengan kisaran nilai 412. Pada kelompok perlakuan, peningkatan nilai pretes ke postes adalah 7,83 (SD 2,839) dengan kisaran nilai 4-12.
Peningkatan rata-rata nilai pretes, peer assessment, dan postes masing-masing item dapat dilihat pada Gambar 3 di bawah.

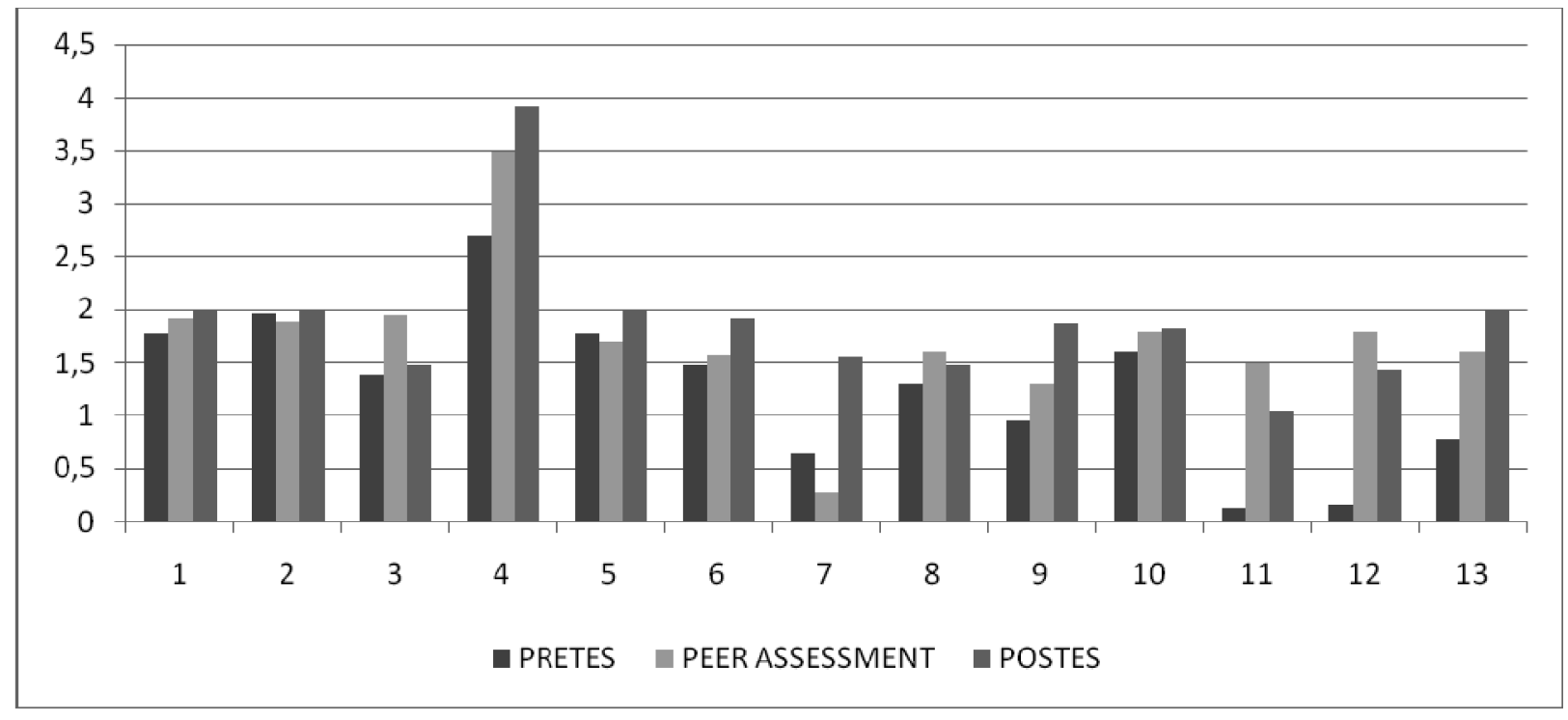

Gambar 3. Nilai rata-rata pretes, peer assessment, dan postes per item pertanyaan pada kelompok perlakuan

Hasil uji normalitas untuk data pretes (perlakuan =0,368; kontrol $=0,685)$, postes $($ perlakuan $=0,645$; ontrol $=$ $0,602)$, dan rata-rata peningkatan nilai (perlakuan $=$ 0,823; kontrol $=0,910$ ). Pada tingkat signifikansi $p>0,05$, sebaran data tersebut normal. Hasil uji homogenitas untuk data pretes 0,415 ; postes 0,944 ; dan rata-rata peningkatan nilai 0,386 . Ketiga data tersebut homogen karena nilai $\mathrm{p}>0,05$. 
Nilai p yang didapatkan pada uji student t peningkatan nilai rata-rata adalah 0,907 dengan rerata (mean difference) sebesar-0,091.

\section{PEMBAHASAN}

Pada hasil uji hipotesis diperoleh nilai $\mathrm{p}=0,907$ yang artinya tidak terdapat perbedaan bermakna antara peningkatan nilai rata-rata pada kelompok kontrol dan kelompok perlakuan. Rerata perbedaan adalah -0,091, yang artinya peningkatan nilai rata-rata pada kelompok kontrol lebih tinggi dari kelompok perlakuan. Berbeda dengan penelitian yang dilakukan oleh Perera et al. bahwa terdapat peningkatan keterampilan komunikasi mahasiswa setelah mahasiswa diberi perlakuan melakukan peer feedback dan self assessment di laboratorium medik. ${ }^{(14)}$ Hal serupa juga terdapat pada penelitian yang dilakukan oleh Schonrock-Adema et al., bahwa terdapat peningkatan nilai performa perilaku profesional pada kelompok mahasiswa yang mendapat perlakuan peer assessment dibandingkan kelompok yang tidak mendapat perlakuan. ${ }^{(15)}$

Bila ditelusuri perubahan nilai masing-masing item pertanyaan saat pretes, praktek peer assessment, dan postes pada kelompok perlakuan, dapat dilihat adanya 3 macam pola peningkatan nilai. Persamaan pada ketiga pola tersebut adalah terjadi peningkatan pada nilai pretes menuju postes, akan tetapi terdapat perbedaan pada pola nilai saat praktek peer assessment. Pola pertama yaitu terdapat pada 6 item pertanyaan yang nilai rata-ratanya mengalami peningkatan mulai dari pretes, kemudian meningkat pada peer assessment, lalu postes. Topping mengemukakan bahwa untuk dapat menilai, assessor harus mengetahui dahulu yang akan dinilai, sehingga akan belajar lebih keras untuk dapat memahami standar dan kriteria yang harus dinilai. Bagi assessee, perlu mempelajari materi karena akan dinilai. ${ }^{(8)}$

Pola kedua adalah pada 3 item pertanyaan lainnya yang terdapat peningkatan rata-rata nilai dari pretes ke postes, akan tetapi rata-rata nilai pada pretes lebih tinggi dari nilai peer assessment. Nilai yang rendah saat praktek peer assessment memotivasi mahasiswa untuk belajar dan berlatih lebih banyak agar dapat memperbaiki nilai yang kurang. Sargeant et al. mengemukakan bahwa feedback, terutama yang negatif, menimbulkan respon reflektif.
Respon reflektif ini yang menjembatani antara penerimaan feedback kemudian mengubahnya menjadi proses usaha untuk perbaikan. ${ }^{(16)}$ Kesenjangan yang terjadi pada nilai pretes dan nilai peer assessment dapat disebabkan karena pemahaman mahasiswa yang masih dangkal terhadap standar. Unsur subjektivitas mahasiswa dalam menilai mahasiswa lain pun dapat terjadi. Vu \& Dall'Alba menyatakan bahwa terdapat keragu-raguan pada mahasiswa apakah temannya menilai dengan adil dan akurat. ${ }^{(9)}$

Pola ketiga terdapat pada 4 item pertanyaan lain, yaitu terjadi penurunan nilai dari peer assessment ke postes. Nilai rata-rata peer assessment lebih tinggi daripada nilai postes pada pola ini. Hal ini bisa terjadi karena perlakuan mahasiswa yang berbeda antara feedback atau penilaian yang positif dan negatif. Pada penilaian negatif, mahasiswa berusaha untuk belajar dan berlatih banyak untuk memperbaiki, sedangkan pada penilaian positif, mahasiswa cenderung tidak memperhatikan karena merasa sudah menguasai:

“...Jadi untuk yang difeedback itu, kita terpacu untuk memahami, tapi untuk yang tidak difeedback, saya rasa biasa saja, jadi saya tidak latih lagi yang tidak difeedback. Jadi yang saya latih lagi dan terpacu di ingatan Cuma yang difeedback saja. Kan yang sisanya saya merasa sama dengan yang lain, jadi saya nda perlu terlalu gencar untuk menguasai. Cuma yang kurang saja, yang saya tambah dan tambah." M4.R2.358-364

Sargeant et al. mengemukakan bahwa dalam proses penerimaan feedbacksampai penggunaan feedback sebagai perbaikan, terdapat proses refleksi dan pengambilan keputusan. Respon assessee terhadap feedback yang diterima terbagi menjadi 2 , yaitu respon terhadap feedback positif dan negatif. Pada feedback positif, respon emosional yang muncul adalah menerima feedback. Proses refleksi terjadi dalam waktu singkat disusul dengan penerimaan feedback, kemudian terdapat 2 kemungkinan yang bisa terjadi setelahnya, yaitu feedback tidak ditindaklanjuti atau feedback ditindaklanjuti sebagai self assessment. ${ }^{(16)}$ Temuan di atas juga diperkuat oleh pendapat yang dikemukakan oleh Kluger \& DeNisi, bahwa tidak semua intervensi feedback dapat meningkatkan performa. Pada penelitian metaanalisis yang dilakukan oleh Kluger \& DeNisi, terdapat sepertiga kasus yang menunjukkan 
penurunan performa pada intervensi feedback. Terdapat 3 hal yang mempengaruhi efek feedback terhadap performans berdasarkan dari konstruksi teori kontrol (control theory), yaitu regulasi feedback standard discrepancy, locus of attention, dan task complexity. Khususnya pada locus of attention, setiap orang memiliki 3 lokus perhatian, yaitu lokus pada diri sendiri (to the self), pada tugas (to the task), dan pada rincian tugas (to the details of the task). Setiap orang memiliki penilaian mengenai yang telah mereka kuasai, yang harus mereka kuasai, dan yang ideal mereka kuasai mengenai suatu tugas. Perlakuan terhadap perbedaan antara yang telah dikuasai dengan yang harus dikuasai dan perlakuan terhadap perbedaan antara yang telah dikuasai dengan yang ideal dikuasai tidak sama. Pengaruh intervensi feedback menunjukkan adanya usaha dalam mendorong meningkatkan performans sampai sesuai dengan standar yang harus dikuasai. Lain halnya bila standar tersebut telah dipenuhi atau bahkan lebih di atas, maka akan terjadi penyesuaian dengan standar atau penurunan performans. ${ }^{(17)} \mathrm{Hal} \mathrm{di}$ atas menjelaskan terjadinya penurunan nilai pada beberapa item ceklis. Standar yang digunakan oleh mahasiswa kemungkinan adalah standar antar mahasiswa, yang tercipta secara tidak langsung dan tanpa disadari oleh mahasiswa.

Selain itu, mahasiswa hanya bergantung pada praktek peer assessment saat belajar karena merasa sudah menguasai keterampilan:

“...pas mau dekat responsi itu, saya tidak mempelajari ceklis lagi, karena menurut saya apa yang sudah saya dapatkan baik pada PAyang kemudian dinilai oleh temanteman lalu mereka memperbaiki apa kesalahan saya, terkadang itu lebih melekat di ingatan saya. Jadi saya tidak ulang lagi, saya langsung responsi, jadi tidak ada persiapan lagi..." M3.R1.170-176

Rata-rata peningkatan nilai pada kelompok perlakuan yang lebih rendah dibandingkan dengan kelompok kontrol kemungkinan disebabkan oleh beberapa hal. Pertama, metode pelatihan peer asessment hanya meliputi penyampaian materi, latihan, diskusi, kemudian evaluasi. Mahasiswa belum diberi kesempatan untuk merefleksikan pengalaman melakukan peer assessment. Menurut Bond \& Spurrit ${ }^{(18)}$, dalam menguasai keterampilan, mahasiswa melalu tahapan-tahapan mulai dari fase kognitif, fase pencapaian keterampilan secara tertutup, fase pencapaian keterampilan secara terbuka, sampai fase otomatisasi. Waktu pelaksanaan pelatihan yang cukup singkat membuat penguasaan keterampilan mahasiswa dalam menilai masih kurang.

Kedua, materi pelatihan peer assessment hanya mencakup keterampilan menilai, tetapi mahasiswa tidak dilatih lagi mengenai penguasaan konten yang akan dinilai. Hal ini menyebabkan ketidaksiapan dalam menilai secara optimal. Ketiga adalah karakteristik mahasiswa. Lemahnya daya saing yang terbentuk pada diri mahasiswa dipengaruhi oleh budaya setempat. Mahasiswa cenderung membandingkan kemampuan dirinya dengan kemampuan temannya. Usaha dalam memperbaiki diri berkurang bila kemampuan mahasiswa lebih daripada kemampuan temannya. Hal ini terlihat pada penilaian peer assessment yang positif membuat mahasiswa cenderung untuk tidak ditindaklanjuti. Hal ini kemungkinan disebabkan oleh pembentukan standar pencapaian oleh mahasiswa itu sendiri. Akan tetapi, yang sangat disayangkan, standar yang terbentuk tersebut masih di bawah standar baku yang ditetapkan oleh institusi, dan mahasiswa tidak menyadarinya.

\section{KESIMPULAN}

Peningkatan rata-rata nilai pada kelompok kontrol lebih tinggi daripada kelompok perlakuan, walaupun secara perhitungan statistik perbedaan peningkatan tersebut tidak bermakna. Walaupun demikian, aplikasi metode peer assessment dapat dilaksanakan di skills laboratory dengan lebih memperhatikan kesiapan dan kemampuan mahasiswa dalam menilai. Hal ini dapat dicapai dengan cara pelatihan yang intens dan selalu diawasi oleh instruktur yang selalu memberikan feedback, dan dengan didukung penuh oleh fakultas.

\section{SARAN}

Untuk masa mendatang perlu dilaksanakan penelitian lanjut dengan pendekatan kualitatif action research mengenai pelaksanaan peer assessment.

\section{DAFTAR PUSTAKA}

1. Ormrod JE. Human learning, 4th ed. New Jersey: Pearson Prentice Hall. 2004;425-38. 
2. Tim Pengembangan Kurikulum PSPD Untad. Kumpulan Data Program Studi Pendidikan Dokter Untad. Palu: Program Studi Pendidikan Dokter Untad. 2010.

3. Boud D, Cohen R \& Sampson J. Peer learning and assessment. Assessment \& Evaluation in Higher Education. 1999; 24(4):413-27.

4. Topping KJ. Peer assessment. Theory Into Practice. 2009; 48:20-7.

5. Weyrich P, Celebi N, Schrauth M, Möltner A, Lammerding-Köppel M \& Nikendei C. Peer-assisted versus faculty staff-led skills laboratory training: a randomised controlled trial. Medical Education. 2009;43:113-20.

6. Hammond M \& Collins R. Self-directed learning: critical practice. London: Kogan Page Limited. 1997;188-9.

7. Liu N \& Carless D. Peer feedback: the learning element of peer assessment. Teaching in Higher Education. 2006;11(3):279-90.

8. Topping K. Peer assessment between students in colleges and universities. Review of Educational Research. 1998;68(3):249-276.

9. Vu TT \& Dall' Alba G. Students' experience of peer assessment in a professional course. Assessment \& Evaluation in Higher Education. 2007;32(5):541-56.

10. Kollar I \& Fischer F. Peer assessment as collaborative learning: a cognitIve perspective. Learning and Instruction. 2010;20:344-8.

11. Nofziger AC, Naumburg EH, Davis BJ, Mooney CJ $\&$ Epstein RM. Impact of peer assessment on the professional development of medical students: a qualitative study. Academic Medicine. 2010; 85:1407.

12. McLoughlin C \& Luca J. An investigation of the motivational aspects of peer and self-assessment tasks to enhance teamwork outcomes. In R. Atkinson, C. McBeath, D. Jonas-Dwyer \& R. Phillips (Eds), Beyond the comfort zone: Proceedings of the 21st ASCILITE Conference (pp. 629-636.Perth,5-8December. http:/ /www.ascilite.org.au/conferences/perth04/ mcloughlin.html

13. Moreno JA, Gonzalez-Cutre D, Martin-Albo J \& Cervello E. Motivation and performance in physical educaion: an experimental test. Journal of Sport Science and Medicine. 2010; 9:79-85.

14. Perera J, Mohamadou G \& Kaur S. The use of objective structured self-assessment and peer-feedback (OSSP) for learning communication skills: evaluation using a controlled trial. Adv in Health Sci Educ. 2010;15:185-93.

15. Schönrock-Adema J, Heijne-Penninga M, van Duijn MAJ, Geertsma J \& Cohen-Schotanus J. Assessment of professional behaviour in undergraduate medical education: peer assessment enhances performance. Medical Education. 2007; 41:836-42.

16. Sargeant JM, Mann KV, van der Vleuten CP \& Metesemakers JF. Reflection: a link between receivig and using assessment feedback. Adv in Health Sci Educ. 2009; 14:399-410.

17. Kluger, A.N. \& DeNisi, A. Feedback interventions: towards the understanding of double-edged sword. Current Directions in Psychological Science. 1998;7(3): 67-91.

18. Bond H. \& Spurritt D. Learning practical skills. In: Higgs J, Edwards H, editors. Educating Beginning Practitioners. Oxford: Butterworth-Heinemann. 1999. 